\title{
Donor effect on cultured pearl nacre development and shell matrix gene expression in Pinctada margaritifera reared in different field sites
}

\author{
Ky Chin-Long ${ }^{1}$, Broustal Floriane ${ }^{1}$, Sham Koua Manaarii ${ }^{1}$, Quillien Virgile ${ }^{1}$, Beliaeff Benoit ${ }^{1}$ \\ ${ }^{1}$ Ifremer, UMR EIO 241, Labex Corail, Centre du Pacifique, BP 49, 98719 Taravao, Tahiti - Polynésie \\ Française
}

\begin{abstract}
:
Understanding the respective roles played by donor and recipient pearl oysters in pearl quality determination in relation to the environment is a challenge for the pearl industry. In most Pinctada species, pearl size is mainly related to recipient oyster growth performance, but also relies to some extent on the biomineralisation activity of the pearl sac, a tissue that originates from the donor oyster mantle. We examined donor effect on pearl size in response to culture in the lagoons on Arutua and Apataki atolls. Overall nacre weight and thickness were greater in Arutua than in Apataki, but sensitivity to the environment differed between donors. Some donors were associated with significantly heavier and thicker nacre in Arutua (I group), while others had similar results at the two sites (NI group). On average, up to $20 \%$ of the pearl size could be attributed to the donor but, in group I, donor effect was responsible for up to $36 \%$ of nacre weight determination. Additionally, a real-time PCR expression study of eight matrix protein genes related to biomineralisation in the pearl sac showed that MSI60, pearlin and pif177 were significantly and positively correlated with nacre weight and thickness, with the latter two genes explaining the larger pearl size observed in Arutua. Donor oysters in P. margaritifera therefore play a key role in pearl size improvement, related to the role of the shell matrix protein genes. Understanding such contributions could help in the design of genetic selection plans for specific and adapted donor oyster lines.
\end{abstract}

Keywords : Pearl oyster, Pinctada margaritifera, Pearl size, Biomineralization, Environment 


\section{Introduction}

The biomineralisation process leading to pearl formation is still poorly understood and, after the point of nucleus implantation into a recipient oyster, the producer has limited control over how a pearl develops. Many studies have focused on oyster shell formation because the nacreous layer of shells is structurally similar to the nacreous layer of pearls. Since the first nacre-shell protein, nacrein, was reported in 1996 (Miyamoto, Miyashita, Okushima, Nakano, Morita \& Matsushiro 1996), dozens of shell matrix proteins have been identified that contribute to the molecular mechanism underlying shell and pearl development, playing important roles in crystal nucleation, orientation, polymorph morphology (Gao, Chen, Yang, Liang, Xie, Liu, Li Zheng, Xie \& Zhang 2016). Some genes are involved in the formation of nacreous aragonite, such as pif (Suzuki, Saruwatari, Kogure, Yamamoto, Nishimura, Kato \& Nagasawa 2009; Zhao, He, Huang \& Wang 2014), MSI60 (Sudo, Fujikawa, Nagakura, Ohkubo, Sakaguchi, Tanaka, Nakashima \& Takahashi 1997) and pearlin (Suzuki \& Nagasawa 2013; Miyashita, Takagi, Okushima, Nakano, Miyamoto, Nishikawa \& Matsushiro 2000; Montagnani, Marie, Marin, Belliard, Riquet, Tayale, Zanella-Cleon, Fleury, Gueguen, Piquemal \& Cochennec-Laureau 2011). Other genes are involved in the prismatic calcite, such as aspein (Tsukamoto, Sarashina \& Endo 2004; Takeuchi, Sarashina, Iijima \& Endo 2008), the shematrin family (Joubert, Picquemal, Marie, Manchon, Pierrat, Zanella Cléon, Cochennec-Laureau, Gueguen, Montagnani 2010; Marie, Joubert, Tayalé, ZanellaCléon, Belliard, Piquemal, Cochennec-Laureau, Marin, Gueguen \& Montagnani 2012) and nacrein, a gene that is found in both the nacreous and prismatic layers of the shell (Miyamoto et al. 1996; Suzuki \& Nagasawa 2013). The role of the matrix proteins in crystal formation was examined by Addadi (1985) and Belcher, Wu, Christensen, Hansma, Stucky \& Morse (1996). 
The quality of a Tahitian pearl is judged on the smoothness and uniformity of its nacreous surface, with overall pearl value determined by five traits: size, shape, lustre, grade and colour (Ky, Blay, Sham Koua, Vanaa, Lo \& Cabral 2013). Selection of donor and recipient oysters are key steps at the beginning of the pearl culturing process. Each of these oysters, via their own genetically-based characteristics, may contribute to one or more pearl quality traits. It is important to elucidate which contributions are made by the donor and/or recipient oyster. The quality of cultured pearls depends greatly on the selection of appropriate donor oysters (Taylor 2002). These are first inspected to assess health and the quality and colour of the nacre lining the inside of their shells (Ky, Lo \& Planes 2017a). Most evidence reported to date in $P$. margaritifera suggests that, while many pearl characteristics (such as colour and lustre) are dictated by the graft donor (Ky et al. 2013, 2017a, Ky, Le Pabic, Sham Koua, Molinari, Nakasai \& Devaux 2017b; McGinty, Evans, Taylor \& Jerry 2010; Tayale, Gueguen, Treguier, Le Grand, Cochennec-Laureau, Montagnani \& Ky 2012), the eventual size of the pearl is mainly dictated by biometric parameters of the recipient (Le Pabic, Parrad, Sham Koua, Nakasai, Saulnier, Devaux \& Ky 2016; Ky, Cabral \& Lo 2017c). In P. fucata, the phenotypic correlation between recipient shell weight and pearl size was examined and a positive relationship was found whereby recipient oysters with heavier valves produced larger pearls (Wada \& Komaru 1996).

Environmental factors play a key role in pearl quality trait determination, especially in French Polynesia, where numerous farms and grow-out sites are geographically distant and subject to disparate regimes. This results in pearl quality trait signatures at the archipelago scale (Ky, Okura, Nakasai \& Devaux 2016a). Understanding the interactions between these animals and their environment is essential for ensuring maximum genetic gains when multiple grow-out locations are used or when different markets are targeted for the end product (Wada \& Jerry 2008). To date, there have been few studies on family-specific interactions with the 
environment for pearl quality traits. Genotype by environment $\left(\mathrm{G}^{*} \mathrm{E}\right)$ interaction on cultured pearl size, colour, weight, shape and lustre were estimated on P. maxima reared at two commercial grow-out locations in Indonesia (Bali and Lombok) (Jerry, Kvingedal, Lind, Evans, Taylor \& Safari 2012). This work showed that pearl size has a heritable basis on the donor oyster side. They also reported significant interactions due to differential ranking of families based on their relative performances at the two commercial grow-out locations used. It is therefore possible that selection for faster growing donor oysters might also improve the pearl size (Le Pabic et al. 2016).

Recent adoption of hatchery-based technologies is a positive step towards the implementation of large-scale selective breeding programmes aiming to increase the prevalence of desirable pearl traits in French Polynesia (Ky \& Devaux 2016a). To date, no studies have been designed to estimate donor oyster effect in response to environment on cultured pearl size (assessed by nacre weight and thickness measurements) in $P$. margaritifera. The present study was based on an experimental graft design, where the grafting process was kept as uniform as possible by using the same expert grafter, nucleus size, graft site and method (the standard method used in commercial grafting), and sources of donor and recipient oysters. To isolate donor effect in response to the environment, grow-out was then conducted in two locations: Arutua and Apataki atoll lagoons (Tuamotu archipelago). At harvest time, correlations between nacre weight / thickness and the level of expression of a set of eight genes implicated in the biomineralisation process in the pearl sac were analysed. 


\section{Materials and methods}

\section{Experimental animals and grafting design}

This study was conducted with wild $P$. margaritifera collected as spat in the lagoons of Takume and Ahe atolls (Tuamotu archipelago, French Polynesia). Passive techniques were employed for catching spat using commercial spat collectors made from modern synthetic materials, to which planktonic mollusc larvae become attached fifteen to twenty days after their release. After nearly two years of subsurface rearing (3-5 m below the surface) and two months prior to the grafting operation, the collectors were transferred by sea to Arutua atoll $\left(15^{\circ} 10^{\prime} \mathrm{S}, 146^{\circ} 49^{\prime} \mathrm{W}\right.$, Tuamotu archipelago, French Polynesia).

As specificities of the grafting operation particular to individual grafters may influence cultured pearl quality, all grafts were made by a single professional technician in a commercial site in Arutua atoll (Tuamotu archipelago) in October 2013. A total of 24 donors from Takume with a mean $( \pm \mathrm{SE})$ anteroposterior measurement of $110.13( \pm 8.86) \mathrm{mm}$ and dorso-ventral measurement of $119.54( \pm 12.03) \mathrm{mm}$ were selected by expert grafters following a two-step procedure (Southgate \& Lucas 2008). In the first step of this procedure, the grafter selects a healthy pearl oyster, which is identifiable by the colour of the visceral mass and gills (brilliant appearance), shell size and appearance (round shape suggesting regular growth), and muscle resistance to prising the shells open to view the interior. In the second step, each oyster is checked for its inner shell colour phenotype by using a speculum to slightly open the valves of the set of healthy pearl oysters. A dentist's mirror is then inserted into the open oyster to be able to see the inner shell colouration, and particularly the contact area (band colour) with the mantle at the edge of the shell. Other areas of the inner shell that are not in contact with the mantle are white in colour in P. margaritifera. Oysters with a colourful band are then selected as saibo donors. In the present experiment, 24 selected 
oysters were used to perform 950 grafts (40 grafts per donor, except for one donor from which only 30 grafts could be made) over a 3-day period under the same conditions as for a commercial graft. Following this method, small strips of epithelium are first prepared before grafts of approximately $4 \mathrm{~mm}^{2}$ are cut and transplanted into the recipient oysters. Each recipient pearl oyster from Ahe was randomly selected from a healthy pool of oysters for grafting. Each recipient was grafted by placing a $2.4 \mathrm{BU}$ nucleus $(7.304 \mathrm{~mm}$ diameter Nucleus Bio, Hyakusyo Co. Japan) together with a single piece of saibo into the gonad. The maximum time between saibo preparation and its use for pearl grafting was less than 30 min.

At 49 days after the grafting operation, recipient oysters were checked to estimate nucleus retention, nucleus rejection and oyster mortality rates, which were done as described in Ky, Nakasai, Molinari \& Devaux (2015a). After this check, recipient oysters that had retained their nuclei were drilled and randomly fixed to a panel net (on the panel net, oysters were attached to a plastic mesh with a monofilament fishing line) in two groups, after removing the net retention bags. As each panel net was labelled according to the corresponding donor oyster (for traceability between donor and recipient), each donor oyster was represented by two panel nets. To evaluate site-specific environment influences on donor-mediated cultured pearl quality traits, the 48 panel nets (each specific to a single donor oyster) were split into two groups to be reared in two culture sites ( 24 panel nets per site), with each donor equally represented at the two sites. One of the two groups (407 oysters) was transferred by sea to Apataki atoll $\left(15^{\circ} 14^{\prime} \mathrm{S}, 146^{\circ} 32^{\prime} \mathrm{W}\right)$, whereas the other (418 oysters) was kept on Arutua atoll. The oysters on panel nets were maintained out of water for two hours. This standardised duration permitted the transfer by sea to Apataki. Furthermore, pearl oysters were regularly cleaned at both sites, during the same periods and at the same frequency in order to remove biofouling (epibiota), over a period of 18 months before the cultured pearls were harvested and graded (March 2015) (Figure 1). 


\section{Measurement of cultured pearl quality traits}

After 18 months of culture at the Arutua and Apataki sites, the cultured pearls were harvested and placed into a compartmented box that allowed traceability between sample pearls and corresponding donor oysters. Some keshi (small, irregularly shaped, nacreous but non-nucleated pearls that form following nucleus rejection) could also be harvested, but not graded. Cultured pearls were then cleaned by ultrasonication in soapy water (hand washing) with a LEO 801 laboratory cleaner (2-L capacity, $80 \mathrm{~W}, 46 \mathrm{kHz}$ ) according to $\mathrm{Ky}$ et al. (2013).

Cultured pearl quality traits: surface defects, lustre, shape, circle, darkness level, and colour categories were evaluated visually (no magnification devices, such as a jeweller's loupe, were used) by two operators working in cooperation, as described in Ky et al. (2013).

Pearl size was assessed by nacre thickness and nacre weight, which were measured as described in Ky et al. (2013).

\section{Biomineralisation gene expression in the pearl sac}

During the harvest operation, one pearl sac of $P$. margaritifera per panel net (i.e., one per donor per site) was randomly sampled $(\mathrm{n}=48)$, preserved in RNAlater (Qiagen) (50 mg $\mathrm{mL}^{-1}$ ) and stored at $-80^{\circ} \mathrm{C}$ until RNA extraction.

After removing the RNAlater by pipetting and absorption, total cellular RNA was extracted from the harvested pearl sacs using TRIzol@ reagent (Life Technologies), according to the manufacturer's recommendations. Total RNA was treated with DNAse I using a DNAfree Kit (Ambion) following the manufacturer's instructions. RNA concentration was quantified using a NanoDrop ND-1000 spectrophotometer (NanoDrop Technologies, Inc.) at $260 \mathrm{~nm}$ using the conversion factor $1 \mathrm{OD}=40 \mu \mathrm{g} \mathrm{m} \mathrm{L} \mathrm{L}^{-1} \mathrm{RNA}$. For each sample, $0.5 \mu \mathrm{g}$ total RNA was reverse-transcribed using a Transcriptor First Strand cDNA Synthesis Kit (Roche) 
and a mix of poly (dT) and random hexamer primers. Real-Time PCR amplifications were carried out on a Stratagene MX3000P system.

The expression level of eight biomineralisation-related genes was analyzed by quantitative Real-Time PCR (qRT-PCR) using a set of forward and reverse primers (Table 1): four implicated in calcite formation: shematrin9 (shem9), aspein, KRMP7 and nacrein, and four implicated in aragonite production: MRNP34, MSI60, pif177 and pearlin. Two other genes were used as housekeeping genes: gapdh1 (Lemer, Saulnier, Gueguen \& Planes 2015) and sage 1 (called REF in Joubert, Linard, Le Moullac, Soyez, Saulnier, Teaniniuraitemoana, Ky \& Gueguen 2014). The amplification reaction contained $12.5 \mu \mathrm{L} 2 \mathrm{X}$ SYBR green qPCR Master Mix (Stratagene), $10 \mu \mathrm{L}$ cDNA template, and $2.5 \mu \mathrm{L}$ of the gene primers $(4 \mu \mathrm{M})$ in a final volume of $25 \mu \mathrm{L}$. Each run included a positive cDNA control and a blank control (water) for each primer pair. Relative gene expression was calculated using the two reference genes, gapdh1 and Sage 1 , by the $2^{-\Delta \Delta \mathrm{Ct}}$ threshold cycle method (Livak \& Schmittgen 2001), as follows:

$$
\begin{aligned}
& \Delta \mathrm{Ct}_{\text {gene, sample } x}=\mathrm{Ct}_{\text {gene, sample } x}-0.5\left(\mathrm{Ct}_{\text {gapdhl, sample } x}+\mathrm{Ct}_{\text {Sagel, sample } x}\right) \\
& \Delta \Delta \mathrm{Ct}_{\text {gene, sample } x}=\Delta \mathrm{Ct}_{\text {gene, sample } x}-\mathrm{Avg} . \Delta \mathrm{Ct}_{\text {gene, sample } x}, \\
& \text { Relative expression }{ }_{\text {gene, sample } x}=2^{-\Delta \Delta \mathrm{Ct}} \text { gene, sample } x .
\end{aligned}
$$

\section{Statistical analysis}

For qualitative categories such as presence of calcite, circle, colour, darkness, lustre, shape and surface defects, differences between the culture sites were analysed using $\chi^{2}$ tests and Fisher's exact tests when an expected value $<5$ was found. The normality of the quantitative parameters nacre thickness and nacre weight was tested using Shapiro-Wilk tests. Due to the non-normality of the variables, non-parametric Kruskall-Wallis tests were performed to test differences between culture sites. Kruskall-Wallis tests were also used to detect differences in relative gene expression between the two culture sites. 
The same analyses were performed according to donor and allowed us to separate donors into two groups, one with donors influenced by the environment and one with donors not influenced by the environment. Differences between sites were analysed for these two groups for all pearl quality traits using $\chi^{2}$ tests and Fisher's exact tests for qualitative traits and Kruskal-Wallis for quantitative traits.

To evaluate donor effect on pearl quality, a linear mixed-effects model was used. The Bayesian Information Criterion (BIC) was used to select the best model. The chosen model treats nacre weight as a response variable, donor as random effect and culture site as a fixed effect.

All analyses were performed using $\mathrm{R} \odot$ ) version 3.2.3 software ( $\mathrm{R}$ foundation for Statistical Computing. The significant threshold was set at $\mathrm{p} \leq 0.05$.

\section{Results}

\section{Experimental graft}

Among the 950 grafted oysters, the average nucleus retention rate was $87 \%(\mathrm{~N}=825)$, with $12 \%(\mathrm{~N}=116)$ rejection and $1 \%(\mathrm{~N}=9)$ mortality at 49 days post-grafting. After 18 months of culture, 364 pearls and 9 keshi were harvested in Apataki atoll, which corresponded to $90 \%$ and $2 \%$, respectively, of the 407 pearl oysters transferred. The remaining $8 \%$ $(\mathrm{N}=34)$ corresponded to mortalities during the culture period. Nearly the same proportions were observed in Arutua atoll, where 378 pearls (90\%) and 10 keshi (2\%) were harvested with an initial number of 418 pearl oysters. In Arutua atoll, an oyster mortality rate of $7 \%(\mathrm{~N}=30)$ was recorded during the culture period. 


\section{Cultured pearl quality trait variations}

For the two quantitative trait parameters (nacre weight and thickness), inter-site differences were highly significant (Table 2). Nacre weight was $24.2 \%$ higher in Arutua than in Apataki. Likewise, as the correlation coefficient between these two variables was 0.95, average nacre thickness was $17.7 \%$ higher in Arutua in comparison with Apataki.

Inter-site comparison between Arutua and Apataki revealed a significant site effect on cultured pearl shape (Table 2). In Apataki, a higher proportion of round pearls were harvested $(+9.6 \%)$. By contrast, the Arutua site produced 9.3\% more baroque pearls than the Apataki site.

No significant differences were detected between the two culture sites for any of the other qualitative trait parameters (Table 2).

Table 3 shows which donors that were influenced by culture site and which were not. For a half of the donors $(\mathrm{N}=12)$, no differences (group NI donors) were detected for any of the quality trait variables recorded between the Apataki and Arutua atolls. By contrast, the other half of the donors (group I donors) showed significant differences between the culture sites for: 1) nacre weight, with 52.6\% heavier pearls in Arutua atoll; 2) nacre thickness, which was $36.4 \%$ greater on pearls from Arutua atoll; and, to a lesser extent, 3) the pearl colour.

\section{Donor effect on cultured pearl quality traits}

The linear mixed-effect model made it possible to quantify donor effect. Nacre weight was used as a proxy of pearl quality. This model showed a significant site effect with $0.099 \mathrm{~g}$ $( \pm 0.013)$ heavier pearls harvested in Arutua atoll. Donor effect was responsible for up to $22.0 \%$ of nacre weight determination. When nacre thickness was used as the response variable, pearls had significantly thicker nacre in Arutua, with $0.017 \mathrm{~mm}( \pm 0.002)$. Donor effect was responsible for $20.6 \%$ of nacre thickness determination. 
For the NI group of donors, where there was no significant site effect for either nacre weight or thickness, donor effect was responsible for $18.8 \%$ of nacre weight and $19.6 \%$ of nacre thickness determination.

For the I group of donors, there were significant site effects for the two parameters with in both cases. In this case, donors were responsible for $22.7 \%$ of nacre thickness determination and up to $36.0 \%$ of nacre weight.

\section{Correlation between nacre weight and thickness and gene expression level}

Nacre weight was significantly correlated with pearlin, pif177 and MSI60 gene expression levels, with correlation coefficients of $0.77,0.59,0.58$, respectively, in Arutua. In Apataki nacre weight was only correlated with MSI60 with of correlation coefficient of 0.59 (Figure 2). The same tendency was observed for nacre thickness, which was significantly correlated with the same three genes pearlin (0.75), pif177 (0.61) and MSI60 (0.6) in Arutua and with MSI60 $(0,6)$ in Apataki. For the five other genes, shem9, aspein, KRMP7, MRNP34 and nacrein, no significant correlations were found with nacre weight or thickness, whatever the culture site (Figure 2).

\section{Discussion}

Contribution of the donor oyster to overall pearl size attained is a complex biological process that has been little studied in $P$. margaritifera. A donor effect was detected by Tayale et al. (2012) using wild oysters in a duplicated experimental graft designed to reveal significant difference between donors. In this previous study, the average nacre thickness and cultured pearl weight produced from the extreme donor pearl oysters phenotype showed up to $33 \%$ and $20 \%$ of difference, respectively. McGinty, Zenger, Taylor, Evans \& Jerry (2011) and McGinty, Zenger, Jones \& Jerry (2012) showed by using $P$. margaritifera as recipient and $P$. 
maxima as donor, that this xenograft treatment produced $62 \%$ heavier nacre than seen in the comparable allograft, a specificity of $P$. maxima, which produces larger pearls than $P$. margaritifera. In the present study, cultured pearls harvested in Arutua atoll were on average heavier $(+24.2 \%)$ and thicker $(+17.7 \%)$ than those harvested in Apataki atoll. This is a surprising result as Arutua and Apataki are neighbouring atolls located in the same archipelago (North Tuamotu) and are only separated by $17 \mathrm{~km}$. No significant differences were detected between the two culture sites for any of the other quality trait parameters, except cultured pearl shape, which was close to the significance limit $(p=0.05)$. This difference of weight and thickness resulted from the existence of two types of donor oyster relationship with the environment: the non influenced (NI) and the influenced (I) donors highlighted in the present study. Donor effect determined up to $20 \%$ of nacre weight and thickness. This rate increased to $36 \%$ for the nacre weight, when the I donor group was considered. All these results, suggesting a role of the donor in pearl size realisation, were in accordance with another two-site rearing experiment, conducted in Tahaa island and Rangiroa atoll on P. margaritifera (Ky, Blay, Aiho, Cabral, Le Moullac \& Lo 2015b). In this previous study, five hatchery-produced families were used as donor oysters. Estimation of the donor effect from these five families using the same linear mixed-effect model as used in the present study showed that donor effect varied among families from 9 to $17 \%$ for nacre weight and 7 to $17 \%$ for nacre thickness. This result confirms the significant genetic role that the implanted mantle graft plays in the formation of a cultured pearl. Given the differences in nacreous deposition among the wild donors in the present study, indicated by the NI and I groups, and those shown among hatchery-produced donor families in previous studies (Ky et al. 2015b), there may be advantages to the industry of using donor pearl oysters that exhibit rapid nacreous deposition (Blay, Sham Koua, Vonau, Tetumu, Cabral, \& Ky 2014) because of the importance of size for the value of a cultured pearl. Nevertheless, correlations between pearl 
size and any other pearl quality trait must also be considered to prevent any non-target coselection of less desirable traits. Indeed, nacre weight and thickness have been shown to be correlated with pearl darkness levels, with the palest pearls being the smallest (lowest thickness and weight) (Tayale et al. 2012; Blay et al. 2014).

Nacre thickness and weight are directly correlated with the nacre biomineralization process in $P$. margaritifera. The epithelial cells from the outer surface of the mantle tissue (which lines the inner surface of the shell) are capable of synthesizing different calcium carbonate polymorphs (Wilbur 1964; Watabe 1988; Awaji \& Machii, 2011), which cover the nucleus, as observed by electron microscopy (Zhang \& Xu 2013). The genome of the donor oyster is still present in the pearl sac of the recipient oyster at the end of pearl formation and its influence on the pearl biomineralization process still active (Arnaud-Haond, Goyard, Vonaun, Herbaut, Prou, Saulnier 2007; Masaoka, Samata, Nogawa, Baba, Aoki, Kotaki, Nakagawa, Sato, Fujiwara, Kobayashi 2013). Correlation of cultured pearl nacre weight and thickness with gene expression levels assessed by real-time PCR from a representative panel of matrix protein genes revealed that pif177 and pearlin expression in the pearl sac of $P$. margaritifera were correlated with both nacre weight and thickness in Arutua, but not significantly in Apataki. This finding is in accordance with the higher average nacre weight and thickness found in Arutua. This positive correlation of pif177 gene expression with nacre weight and thickness has already been observed in a previous study comparing nacre weight and thickness between Tahaa island and Rangiroa atoll (Ky et al. 2015b). In this previous study, one of the five hatchery-produced donor families showed the highest pifl 17 gene expression and confirmed the phenotypic observation on the corresponding harvested pearls, the heaviest and the thickest samples. The protein coded by gene pif177 regulates the growth of aragonite crystal and organization of the tablets (Suzuki et al., 2009). This protein has been identified in P. margaritifera (Joubert et al. 2014). Pearlin is involved in the formation of the 
organic matrix framework and serves as a nucleation template, thus inducing calcium carbonate deposition (Miyashita et al. 2000; Miyamoto, Miyoshi \& Kohno 2005). The Pif protein complex, together with Pearlin and other proteins, may be involved in the formation of the lamellar sheet and aragonite crystal regulation of the orientation of the c axis and concentration of calcium carbonate (Suzuki et al., 2009). Only MSI60 gene expression was correlated with pearl size in both culture sites, reflecting its role in nacreous layer formation by regulating aragonite crystal growth (Sudo et al. 1997). No significant correlations between nacre weight and thickness were found for the expression levels of the other five genes (shem9, aspein, KRMP7, MRNP34 and nacrein) in the pearl sac, indicating their relative independence with regards to the growth of pearls in the two culture sites. As other cultured pearl quality traits recorded in the present study were not influenced by site (circles, darkness level, colour categories, lustre and surface defects), these five genes may be implicated in their determination.

\section{Conclusion}

The present study was the first on wild donor effect estimation on cultured pearl nacre weight and thickness in P. margaritifera. In this two-site experimental design, donor effect was found to be responsible for up to $20 \%$ of the nacre weight and thickness determination, the only pearl quality traits significantly affected by the growing environment. Donor oysters could be separated into two groups: those for which nacre weight and thickness were affected by the culture site (I group), and those that seemed to be insensitive to environmental variation (NI group). There is therefore the potential to select and propagate appropriate donors from the I or NI groups for future use in genetic selection, depending on whether the objective is to obtain maximum genetic gains (as with a donor in I group responsible for $36 \%$ of nacre weight) or for diffusing more stable genetic lines for culture in disparate environments (as would be possible with NI donors). 
The results on matrix protein gene expression in the pearl sac revealed the specific involvement of pearlin, pif177 and MSI60 in cultured pearl size determination in $P$. margaritifera. Pearlin and pif177 were significantly correlated with nacre weight $(+24.2 \%)$ and nacre thickness $(+17.7 \%)$ and greater expression levels coincided with a larger average pearl size in the Arutua culture site than in Apataki. Expression of the other genes was not related to nacre weight or thickness, as no correlations were significant for shem9, aspein, KRMP7, MNRP34 and nacrein, which are probably implicated in other pearl quality traits that were not revealed by the present graft design. Such a study would make it possible to elucidate the different roles played by the shell matrix protein gene in the architecture of the cultured pearl quality trait signature in P. margaritifera.

\section{Acknowledgments}

The authors would especially like to thank the host sites, Pahai Poe pearl farm (Apataki atoll - Tuamotu archipelago - French Polynesia) and Pommier pearl farm (Arutua atoll - Tuamotu archipelago - French Polynesia), for their generous support.

\section{References}

Addadi L. \& Weiner S. (1985) Interactions between acidic proteins and crystals: stereochemical requirements in biomineralisation. Proc. Natl Acad. Sci. 82, 4110-4114. (doi:10.1073/pnas.82.12.4110)

Arnaud-Haond S., Goyard E., Vonaun V., Herbaut C., Prou J., Saulnier D. (2007) Pearl formation: persistence of the graft during the entire process of biomineralization. Marine Biotechnology 9, 113-116. 
Awaji, M., Machii, A. (2011). Fundamental Studies on in vivo and in vitro Pearl Formation Contribution of Outer Epithelial Cells of Pearl Oyster Mantle. Aqua-BioScience Monographs 4, 1-39.

Blay C., Sham-Koua M., Vonau V., Tetumu R., Cabral P., \& Ky C. L. (2014) Influence of nacre deposition rate on cultured pearl grade and colour in the black-lipped pearl oyster Pinctada margaritifera using farmed donor families. Aquaculture international 22, 937-953.

Belcher A. M., Wu X. H., Christensen R. J., Hansma P. K., Stucky G. D. \& Morse D. E. (1996) Control of crystal phase switching and orientation by soluble mollusc-shell proteins. Nature 381, 56-58.

Gao J., Chen Y., Yang Y., Liang J., Xie J., Liu J., Li S., Zheng G., Xie L. \& Zhang R. (2016) The transcription factor Pf-POU3F4 regulates expression of the matrix protein genes Aspein and Prismalin-14 in pearl oyster (Pinctada fucata). The FEBS journal 283, 1962-1978.

Jerry D.R., Kvingedal R., Lind C.E., Evans B.S., Taylor J.U. \& Safari A.E. (2012) Donor oyster derived heritability estimates and the effect of genotype $\mathrm{x}$ environment interaction on the production of pearl quality traits in the silver-lip pearl oyster, Pinctada maxima. Aquaculture 338: 66-71.

Joubert, C., Picquemal D., Marie B., Manchon L., Pierrat F., Zanella Cléon I., CochennecLaureau N., Gueguen Y., Montagnani C. (2010). Transcriptome and proteome analysis of Pinctada margaritifera calcifying mantle and shell: focus on biomineralisation. BMC Genomics, 11, 613-626.

Joubert C., Linard C., Le Moullac G., Soyez C., Saulnier D., Teaniniuraitemoana V., Ky C.L. \& Gueguen Y. (2014) Temperature and Food Influence Shell Growth and Mantle Gene Expression of Shell Matrix Proteins in the Pearl Oyster Pinctada margaritifera. PLoS ONE 9(8): e103944. doi:10.1371/journal.pone.0103944

Ky C.L., Blay C., Sham Koua M., Vanaa V., Lo C. \& Cabral P. (2013) Family effect on cultured pearl quality in black-lipped pearl oyster Pinctada margaritifera and insights for genetic improvement. Aquatic Living Resource 26: 133-145. 
Ky C.L., Nakasai S., Molinari N. \& Devaux D. (2015a) Influence of grafter skill and season on cultured pearl shape, circles and rejects in Pinctada margaritifera aquaculture in Mangareva lagoon. Aquaculture 435, 361-370.

Ky C.L., Blay C., Aiho V., Cabral P., Le Moullac G. \& Lo C. (2015b) Macro-geographical differences influenced by family-based expression on cultured pearl grade, shape and colour in the black-lip pearl oyster Pinctada margaritifera: a preliminary case study in French Polynesia. Aquaculture Research, doi: 10.1111/are.12880.

Ky C.L., Okura R., Nakasai S. \& Devaux D. (2016a) Quality Trait Signature at Archipelago Scale of the Cultured Pearls Produced by the Black-Lipped Pearl Oyster (Pinctada margaritifera Var. cumingi) in French Polynesia . Journal of Shellfish Research 35(4), 827835.

Ky C.L. \& Devaux D. (2016b) Polynesian pearls. Hatchery international 17, 20-21.

Ky C.L., Lo C. \& Planes S. (2017a) Mono- and polychromatic inner shell phenotype diversity in Pinctada margaritifera donor pearl oysters and its relation with cultured pearl colour. Aquaculture 468, 199-205.

Ky C.L., Le Pabic L., Sham Koua M., Molinari N., Nakasai S. \& Devaux D. (2017b) Is pearl colour produced from Pinctada margaritifera predictable through shell phenotypes and rearing environments selections? Aquaculture Research , 48(3), 1041-1057.

Ky C.L., Cabral P. \& Lo C. (2017c) Phenotypic indicators for cultured pearl size improvement in the black-lipped pearl oyster (Pinctada margaritifera): towards selection for the recipient growth performance . Aquaculture Research IN PRESS . http://doi.org/10.1111/are.13233

Lemer S., Saulnier D., Gueguen Y. \& Planes S. (2015) Identification of genes associated with shell color in the black-lipped pearl oyster, Pinctada margaritifera. BMC Genomics 15, 568. 
Le Pabic L., Parrad P., Sham Koua M., Nakasai S., Saulnier D., Devaux D. \& Ky C.L. (2016) Culture site dependence on pearl size realization in Pinctada margaritifera in relation to recipient oyster growth and mantle graft biomineralization gene expression using the same donor phenotype. Estuarine, Coastal and Shelf Sci doi: 10.1016/j.ecss.2016.03.009

Livak K.J. \& Schmittgen T.D. (2001) Analysis of relative gene expression data using realtime quantitative PCR and the 2(-Delta Delta C(T)) method. Methods 25, 402-408.

Marie B., Joubert C., Tayalé A., Zanella-Cléon I., Belliard C., Piquemal D., CochennecLaureau N., Marin F., Gueguen Y. \& Montagnani C. (2012) Different secretory repertoires control the biomineralization processes of prism and nacre deposition of the pearl oyster shell. Proc. Natl Acad. Sci. 109, 20986-20991.

McGinty E.L., Evans B.S., Taylor J.U.U. \& Jerry D.R. (2010) Xenografts and pearl production in two pearl oyster species, $P$. maxima and $P$. margaritifera: effect on pearl quality and a key to understanding genetic contribution. Aquaculture 302, 175-181.

McGinty E.L., Zenger K.R., Taylor J.U.U., Evans B.S. \& Jerry D.R. (2011) Diagnostic genetic marker unravel the interplay between host and donor oyster contribution in cultured pearl formation. Aquaculture 304, 20-24.

McGinty E.L., Zenger K.R., Jones D.B. \& Jerry D.R. (2012) Transcriptome analysis of biomineralisation-related genes within the pearl sac: host and donor oyster contribution. Marine Genomics 5, 27-33.

Masaoka T, Samata T, Nogawa C, Baba H, Aoki H, Kotaki T, Nakagawa A, Sato M, Fujiwara A, Kobayashi T (2013) Shell matrix protein genes derived from donor expressed in pearl sac of Akoya pearl oysters (Pinctada fucata) under pearl culture. Aquaculture 384: 56-65.

Miyamoto H., Miyoshi F. \& Kohno J. (2005) The carbonic anhydrase domain protein nacrein is expressed in the epithelial cells of the mantle and acts as a negative regulator in calcification in the mollusc Pinctada fucata. Zoological Science 22, 311-315. 
Miyashita T., Takagi R., Okushima M., Nakano S., Miyamoto H., Nishikawa E. \& Matsushiro A. (2000) Complementary DNA cloning and characterization of pearlin, a new class of matrix protein in the nacreous layer of oyster pearls. Marine Biotechnology 2, 409-418.

Miyamoto H., Miyashita T., Okushima M., Nakano S., Morita T. \& Matsushiro A. (1996) A carbonic anhydrase from the nacreous layer in oyster pearls. Proc Natl Acad Sci USA 93, 9657-9660.

Montagnani C., Marie B., Marin F., Belliard C., Riquet F., Tayale A., Zanella-Cleon I., Fleury E., Gueguen Y., Piquemal D. \& Cochennec-Laureau N. (2011) Pmarg-Pearlin is a Matrix Protein Involved in Nacre Framework Formation in the Pearl Oyster Pinctada margaritifera. Chembiochem, 12(13), 2033-2043

Southgate P.C. \& Lucas J.S. (2008) The Pearl Oyster. Elsevier, Oxford, UK 575 pp.

Sudo S., Fujikawa T., Nagakura T., Ohkubo T., Sakaguchi K., Tanaka M., Nakashima K. \& Takahashi K. (1997) Structures of mollusc shell framework proteins. Nature 387, 563-564.

Suzuki M., Saruwatari K., Kogure T., Yamamoto Y., Nishimura T., Kato T. \& Nagasawa1 H. (2009) An acidic matrix protein, Pif, is a key macromolecule for nacre formation. Science 325, 1388-1390.

Suzuki M. \& Nagasawa H. (2013) Mollusk shell structures and their formation mechanism. Can J Zool 91, 349-366.

Tayale A., Gueguen Y., Treguier C, Le Grand J., Cochennec-Laureau N., Montagnani C. \& Ky C.L. (2012) Evidence of donor effect on cultured pearl quality from a duplicated grafting experiment on Pinctada margaritifera. using wild donors. Aquat. Living Resour. 25, 269-280.

Taylor J.J.U. (2002) Producing golden and silver south sea pearls from Indonesian hatchery reared Pinctada maxima. World Aquaculture 2002, World Aquaculture Society, Baton Rouge LA, USA (2002), p. 754 Beijing, PR China, Apr. 23-27 
Takeuchi T., Sarashina I., Iijima M. \& Endo K. (2008) In vitro regulation of CaCO3 crystal polymorphism by the highly acidic molluscan shell protein Aspein. FEBS Lett 582, 591-596.

Tsukamoto D., Sarashina I. \& Endo K. (2004) Structure and expression of an unusually acidic matrix protein of pearl oyster shells. Biochem Biophys Res Commun 320, 1175-1180.

Wada K.T.\& Jerry D.R. (2008) Population genetics and stock improvement. In: Southgate, P.C., Lucas, J. (Eds.), The Pearl Oyster. Elsevier, Oxford, pp. 437-471.

Wada K. \& Komaru A. (1996) Color and weight of pearls produced by grafting the mantle tissue from a selected population for white shell color of the japanese pearl oyster Pinctada fucata martensii (dunker). Aquaculture 142, 25-32.

Watabe N. (1988) Shell structure. The Mollusca, Trueman E.R. and Clarke M.R. (Eds.), Academic Press, Vol. 11, pp. 69-104.

Wilbur K. (1964) Shell formation and regeneration, Physiology of Mollusca, A. Saleuddin, K. Wilbur (Eds.), Academic P, pp. 243-287.

Zhang G. \& Xu J. (2013) From colloidal nanoparticles to a single crystal: new insights into the formation of nacre's aragonite tablets. Journal of Structural Biology 182, 36-43.

Zhao M., He M., Huang X. \& Wang Q. (2014) A homeodomain transcription factor gene, PfMSX, activates expression of Pif gene in the pearl oyster Pinctada fucata. PLoS One 9, e103830. 
Table 1. Set of forward (F: 5'-3') and reverse (R: 5'-3') primers used for gene expression analysis by quantitative RT-PCR in the pearl sac of Pinctada margaritifera.

\begin{tabular}{|c|c|c|}
\hline Gene & $\begin{array}{l}\text { GenBank } \\
\text { Accession numbers }\end{array}$ & Primer sequence \\
\hline Aspein & SRX022139 & $\begin{array}{l}\text { F TGAAGGGGATAGCCATTCTTC } \\
\text { R ACTCGGTTCGGAAACAACTG }\end{array}$ \\
\hline KRMP7 & ABP57445 & $\begin{array}{l}\text { F GCCTTCACCACAGAAGGAAG } \\
\text { R GCCGAATTTCTTCAGACACC }\end{array}$ \\
\hline MNRP34 & HQ625028 & $\begin{array}{l}\text { F GTATGATGGGAGGCTTTGGA } \\
\text { R TTGTGCGTACAGCTGAGGAG }\end{array}$ \\
\hline MSI60 & SRX022139 & $\begin{array}{l}\text { F TCAAGAGCAATGGTGCTAGG } \\
\text { R GCAGAGCCCTTCAATAGACC }\end{array}$ \\
\hline Nacrein A1 & HQ654770 & $\begin{array}{l}\text { F CTCCATGCACAGACATGACC } \\
\text { R GCCAGTAATACGGACCTTGG }\end{array}$ \\
\hline Shematrin 9 & ABO92761 & $\begin{array}{l}\text { F TGGTGGCGTAAGTACAGGTG } \\
\text { R GGAAACTAAGGCACGTCC }\end{array}$ \\
\hline Pearlin & DQ665305 & $\begin{array}{l}\text { F TACCGGCTGTGTTGCTACTG } \\
\text { R CACAGGGTGTAATATCTGGAACC }\end{array}$ \\
\hline PIF 177 & HE610401 & $\begin{array}{l}\text { F AGATTGAGGGCATAGCATGG } \\
\text { R TGAGGCCGACTTTCTTGG }\end{array}$ \\
\hline
\end{tabular}


Table 2. Quality traits of cultured pearls from Pinctada margaritifera harvested in Apataki (N $=364)$ and Arutua $(\mathrm{N}=377)$ rearing sites. Nomenclature of the traits are as follows: shape $(\mathrm{R}$ : round; O: oval; B: baroque), circle (0: absence or 1: presence), presence of calcite (0: no calcite; 1 : $<20 \%$ calcite ; 2 : >20\% calcite), darkness level (D: high; M: medium; L: low), colour categories (GY: grey; GR: green; P: peacock; A: aubergine; Y: yellow; W: white; B: blue), lustre (1: with or 0 : without lustre) and surface defects (0: no defects; $1: 1$ to 5 defect(s); 2: 6 to 10 defects; 3: more than 10 defects). The first number in each cell indicates the percentage contribution (\%) for each of the quality trait categories. The second entry (in brackets) corresponds to the number of pearls observed in this category. P-values were obtained with Chi-squared tests or Fisher's exact tests. Quality traits significantly different between the two sites at $0.01<p \leq 0.05,0.001<p \leq 0.01$ and $p \leq 0.001$ are indicated with 1 , 2 or 3 asterisk(s) (*), respectively, and NS for not significant.

\begin{tabular}{|c|c|c|c|c|c|}
\hline \multicolumn{2}{|c|}{ Quality traits } & \multicolumn{2}{|c|}{ Apataki } & Arutua & Significance \\
\hline \multicolumn{2}{|c|}{ Nacre thickness (mm) } & \multicolumn{2}{|c|}{$1.13 \pm 0.39$} & $1.33 \pm 0.45$ & $* * *$ \\
\hline \multicolumn{2}{|c|}{ Nacre weight (g) } & \multicolumn{2}{|c|}{$0.813 \pm 0.369$} & $1.010 \pm 0.474$ & $* * *$ \\
\hline \multirow[t]{3}{*}{ Shape } & $\mathrm{R}$ & 39.6 & $(144)$ & $30 \quad(113)$ & \multirow{3}{*}{$*$} \\
\hline & $\mathrm{O}$ & 22 & $(88)$ & $22.3 \quad(84)$ & \\
\hline & B & 38.5 & $(140)$ & $47.7 \quad(180)$ & \\
\hline \multirow[t]{2}{*}{ Circle } & 0 & 60.7 & $(221)$ & $54.6 \quad(206)$ & \multirow{2}{*}{ NS } \\
\hline & 1 & 39.3 & $(143)$ & $45.4 \quad(171)$ & \\
\hline \multirow[t]{3}{*}{ Calcite } & 0 & 89 & (324) & $91.2 \quad(344)$ & \multirow{3}{*}{ NS } \\
\hline & 1 & 7.1 & $(26)$ & 6.4 (24) & \\
\hline & 2 & 3.9 & $(14)$ & $2.4 \quad(9)$ & \\
\hline \multirow[t]{3}{*}{ Darkness } & $\mathrm{D}$ & 51.9 & (189) & $51.2 \quad(193)$ & \multirow{3}{*}{ NS } \\
\hline & M & 39.6 & (144) & $40.8 \quad(154)$ & \\
\hline & $\mathrm{L}$ & 8.5 & $(31)$ & $8(30)$ & \\
\hline \multirow[t]{7}{*}{ Colour } & GY & 69.8 & $(254)$ & $(256)$ & \multirow{7}{*}{ NS } \\
\hline & GR & 14.6 & $(53)$ & $(66)$ & \\
\hline & $\mathrm{P}$ & 12.9 & $(47)$ & $11.1 \quad(42)$ & \\
\hline & A & 1.6 & (6) & 1.6 & \\
\hline & $\mathrm{Y}$ & 0.3 & (1) & 0.5 & \\
\hline & $\mathrm{W}$ & 0.8 & (3) & $0.5 \quad(2)$ & \\
\hline & B & 0 & (0) & $0.8 \quad(3)$ & \\
\hline \multirow[t]{2}{*}{ Lustre } & 0 & 53 & (193) & $(185)$ & \multirow{2}{*}{ NS } \\
\hline & 1 & 47 & $(171)$ & $50.9 \quad(192)$ & \\
\hline Surface & 0 & 3.6 & (13) & $4.8 \quad(18)$ & \multirow{4}{*}{ NS } \\
\hline \multirow[t]{3}{*}{ Defects } & 1 & 29.7 & (108) & $29.2 \quad(110)$ & \\
\hline & 2 & 23.3 & $(85)$ & $(71)$ & \\
\hline & 3 & 43.4 & (158) & (178) & \\
\hline
\end{tabular}


Table 3. Cultured pearl quality traits of Pinctada margaritifera from the groups of donors that either were (I) or were not (NI) influenced by the culture sites (Apataki and Arutua). Nomenclature is as follows: shape (R: round; O: ovale; B: baroque), circle (0: absence or 1: presence), presence of calcite (0: no calcite; 1: -20\% calcite; 2: +20\% calcite), darkness level (D: high; M: medium; L: low), colour categories (GY: grey; GR: green; P: peacock; A: aubergine; Y: yellow; W: white; B: blue), lustre (1: with or 0 : without lustre) and surface defects (0: no defects; $1: 1$ to 5 defect(s); $2: 6$ to 10 defects; 3 : more than 10 defects). The first number in each cell indicates the percentage contribution (\%) of each of the quality trait categories. The numbers in brackets correspond to the number of pearls observed in each category. P-values were obtained with Chi-squared tests or Fisher's exact test for qualitative traits and with Kruskal-Wallis tests for quantitative traits. Quality traits that were significantly different between the two sites are indicated with an asterisk (* at $p>0.05)$ and NS for not significant.

\begin{tabular}{|c|c|c|c|c|c|c|c|c|c|c|c|}
\hline & \multirow{2}{*}{\multicolumn{4}{|c|}{ Non influenced donor }} & \multirow{2}{*}{\multicolumn{5}{|c|}{ Influenced donor }} & \multirow[b]{3}{*}{ Significance } \\
\hline & & & & & & & & & & & \\
\hline \multicolumn{2}{|c|}{ Quality traits } & \multicolumn{2}{|c|}{ Apataki (182) } & \multicolumn{2}{|c|}{ Arutua (194) } & Significance & \multicolumn{2}{|c|}{ Apataki (182) } & \multicolumn{2}{|c|}{ Arutua (183) } & \\
\hline \multicolumn{2}{|c|}{ Nacre thickness $(\mathrm{mm})$} & \multicolumn{2}{|c|}{$0.11 \pm 0.048$} & \multicolumn{2}{|c|}{$0.14 \pm 0.07$} & NS & \multicolumn{2}{|c|}{$0.11 \pm 0.039$} & \multicolumn{2}{|c|}{$0.15 \pm 0.038$} & $*$ \\
\hline \multicolumn{2}{|c|}{ Nacre weight $(\mathrm{g})$} & \multicolumn{2}{|c|}{$0.78 \pm 0.47$} & \multicolumn{2}{|c|}{$1.17 \pm 0.82$} & NS & \multicolumn{2}{|c|}{$0.76 \pm 0.35$} & \multicolumn{2}{|c|}{$1.16 \pm 0.39$} & $*$ \\
\hline \multirow{3}{*}{ Shape } & $\mathrm{R}$ & 36.3 & (66) & 24.7 & $(48)$ & \multirow{3}{*}{ NS } & 40.7 & (74) & 35.5 & $(65)$ & \multirow{3}{*}{ NS } \\
\hline & $\mathrm{O}$ & 21.4 & (39) & 25.8 & (50) & & 22.5 & (41) & 18.6 & (34) & \\
\hline & $\mathrm{B}$ & 42.3 & $(77)$ & 49.5 & (96) & & 36.8 & $(67)$ & 45.9 & $(84)$ & \\
\hline \multirow[t]{2}{*}{ Circle } & 0 & 59.9 & (109) & 52.6 & $(102)$ & \multirow{2}{*}{ NS } & 61.5 & (112) & 56.8 & (104) & \multirow{2}{*}{ NS } \\
\hline & 1 & 40.1 & (73) & 47.4 & $(92)$ & & 38.5 & $(70)$ & 43.2 & (79) & \\
\hline \multirow[t]{3}{*}{ Calcite } & 0 & 85.7 & (156) & 89.7 & (174) & \multirow{3}{*}{ NS } & 92.3 & (168) & 92.9 & $(170)$ & \multirow{3}{*}{ NS } \\
\hline & 1 & 8.8 & (16) & 6.7 & (13) & & 5.5 & (10) & 6 & (11) & \\
\hline & 2 & 5.5 & (10) & 3.6 & (7) & & 2.2 & (4) & 1.1 & (2) & \\
\hline \multirow[t]{3}{*}{ Darkness } & $\mathrm{D}$ & 35.2 & (64) & 33 & (64) & & 68.9 & (125) & 70.5 & (129) & \\
\hline & M & 49.4 & (90) & 54.1 & (105) & NS & 29.7 & (54) & 26.8 & $(49)$ & NS \\
\hline & $\mathrm{L}$ & 15.4 & (28) & 12.9 & $(25)$ & & 1.6 & (3) & 2.7 & (5) & \\
\hline Colour & GY & 67.6 & (123) & 70.1 & (136) & & 72 & (131) & 65.6 & (123) & \\
\hline & GR & 17 & $(31)$ & 18 & $(35)$ & & 12.1 & $(22)$ & 16.9 & $(31)$ & \\
\hline & $\mathrm{P}$ & 12.1 & (22) & 7.7 & (15) & & 13.7 & (25) & 14.8 & (27) & \\
\hline & A & 1.1 & (2) & 3.1 & (6) & NS & 2.2 & (4) & 0 & $(0)$ & $*$ \\
\hline & $\mathrm{Y}$ & 0.5 & (1) & 1 & (2) & & 0 & (0) & 1.1 & (2) & \\
\hline & W & 1.6 & (3) & 0 & (0) & & 0 & (0) & 0 & (0) & \\
\hline & $\mathrm{B}$ & 0 & $(0)$ & 0 & $(0)$ & & 0 & $(0)$ & 1.6 & (3) & \\
\hline Lustre & 0 & 52.2 & (95) & 43.3 & (84) & NS & 53.8 & (98) & 55.2 & (101) & NS \\
\hline & 1 & 47.8 & (87) & 56.7 & (111) & NS & 46.2 & (84) & 44.8 & $(82)$ & NS \\
\hline Surface & 0 & 4.9 & (9) & 5.7 & (11) & & 2.2 & (4) & 3.8 & $(7)$ & \\
\hline Defects & 1 & 35.2 & (64) & 32.5 & (63) & & 24.2 & (44) & 25.7 & (47) & \\
\hline & 2 & 23.6 & (43) & 19.1 & (37) & NS & 23.1 & (42) & 18.6 & (34) & NS \\
\hline & 3 & 36.3 & (66) & 42.8 & (83) & & 50.5 & (92) & 51.9 & (95) & \\
\hline
\end{tabular}


Figure 1: Experimental graft design of P. margaritifera performed in two grow-out sites (atolls of Arutua and Apataki, Tuamotu archipelago).

Grafted recipient oysters providing from each donor oyster were split randomly into two groups; one was left in Arutua and the other transferred to Apataki.

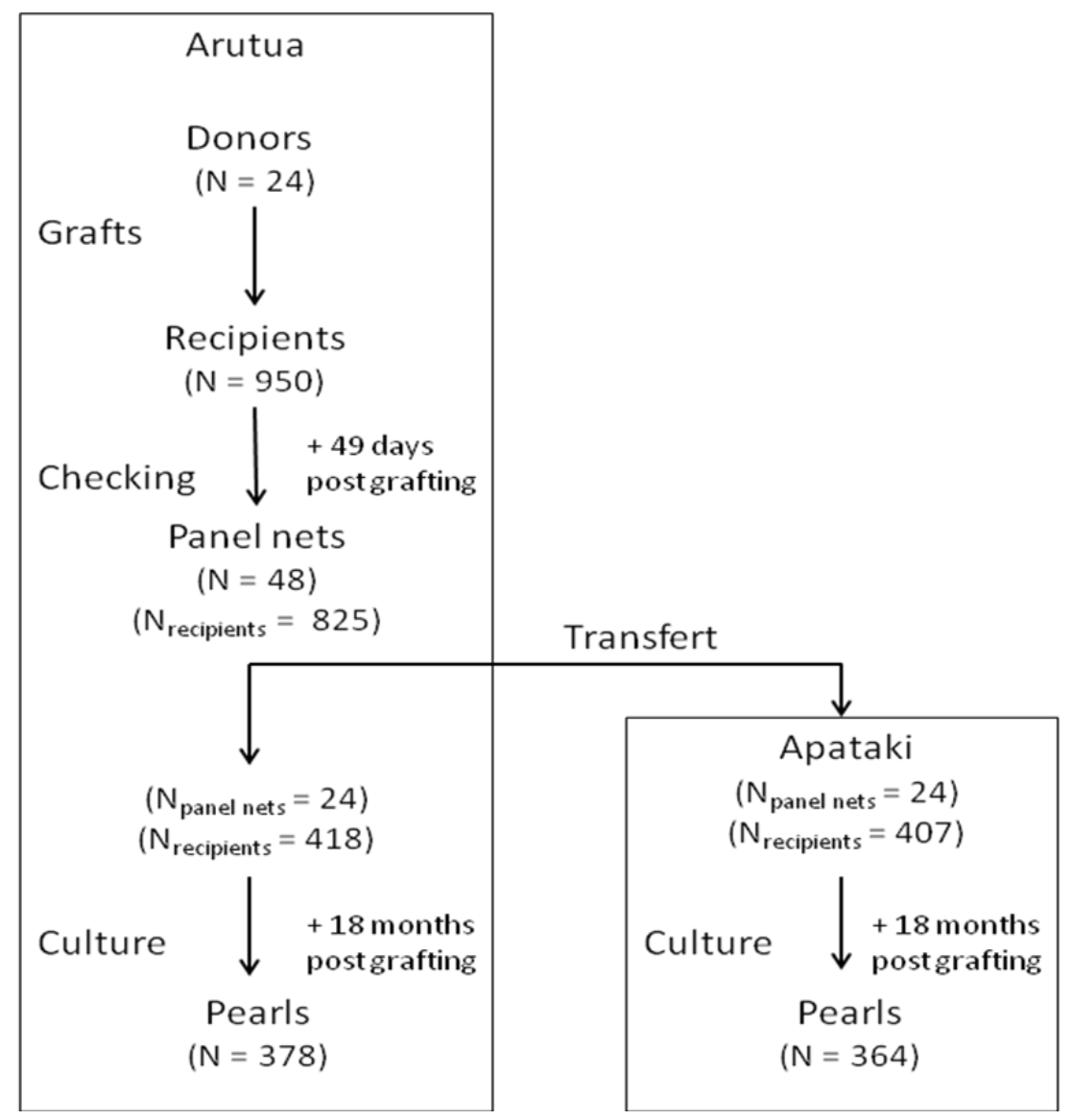


Figure 2: Correlation of the expression levels of eight biomineralisation genes in the pearl sac of $P$. margaritifera at harvest time in culture sites on the Apataki $(\mathrm{N}=24)$ and Arutua atolls $(\mathrm{N}=24)$ with nacre weight $(\mathrm{NW})$ and thickness $(\mathrm{NT})$ of the corresponding cultured pearls. Strength of the correlations is shown by the diameter of the circles and their colour, with negative correlations shown in shades of red and positive ones in green.
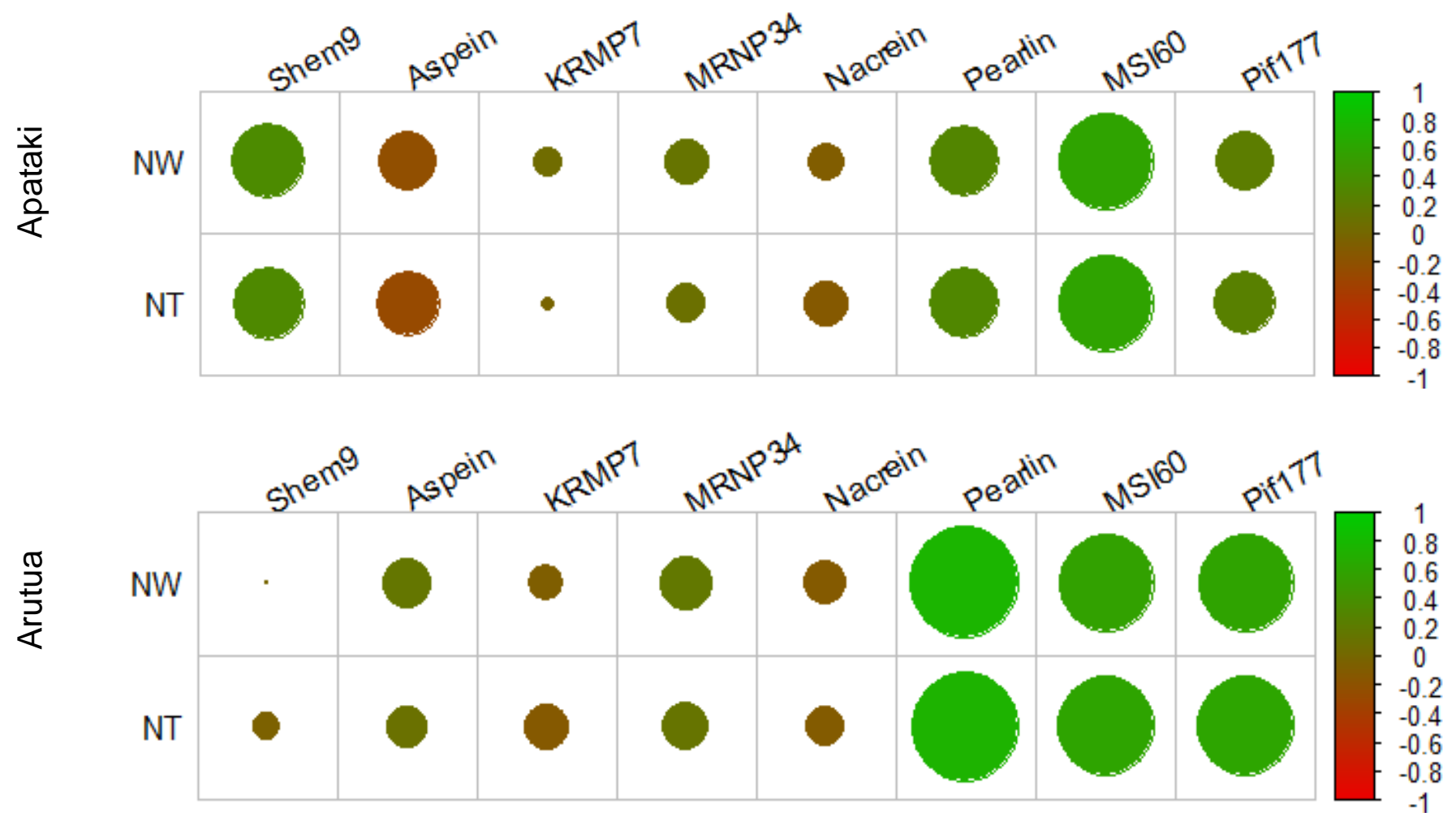